\title{
Leucothoid and Maerid Amphipods (Crustacea) from deep regions of the North Atlantic
}

\author{
T. Krapp-Schickel $\cdot$ W. Vader
}

Received: 23 May 2012/Revised: 4 August 2012/Accepted: 17 August 2012/Published online: 29 September 2012

(C) Springer-Verlag and AWI 2012

\begin{abstract}
From amphipod collections from the deep Norwegian Sea, three species are here redescribed: Maera loveni (Bruzelius 1859) (Maeridae), Leucothoe aff. spinicarpa (Abildgaard, 1789) and L. uschakovi Gurjanova, 1951 (Leucothoidae). A key to all Atlantic and Mediterranean Leucothoe species (males only) is provided.
\end{abstract}

Keywords Amphipoda - Leucothoidae - Maeridae .

Atlantic Ocean

\author{
Pl 1-3 Pleonite 1-3 \\ Pn Peraeonite \\ T Telson \\ U 1-3 Uropod 1-3 \\ Us 1-3 Urosomites 1-3 \\ Tooth Non-articulated pointed ectodermal structure \\ Spine Stout, articulated structure (synonymous to \\ "robust seta") \\ Seta Slender, flexible articulated structure
}

\author{
Abbreviations \\ A 1, 2 Antenna 1, 2 \\ Acc Accessory \\ Art Article \\ Cx 1-7 Coxa 1-7 \\ Ep 1-3 Epimera or epimeral plates \\ Flag Flagellum \\ Gn 1, 2 Gnathopod 1, 2 \\ IP Inner plate \\ Md Mandible \\ Mx 1, 2 Maxilla 1, 2 \\ Mxp Maxilliped \\ OP Outer plate \\ P 3-7 Peraeopod 3-7 \\ Ped Peduncle
}

Communicated by H.-D. Franke.

T. Krapp-Schickel ( $\square)$

Zool. Forschungsinstitut A. Koenig, Adenauerallee 160,

53113 Bonn, Germany

e-mail: Traudl.krapp@uni-bonn.de

W. Vader

Troms $\emptyset$ Museum, 9037 Troms $\varnothing$, Norway

e-mail: wim.vader@uit.no

\section{Introduction}

The amphipod fauna of the deep Norwegian Sea is as yet very insufficiently known. Most of our knowledge still rests on the data from the Norske Nordhavs Expedition (Sars 1885) and the Danish Ingolf Expedition (Stephensen 1923, 1925, 1931, 1944). In recent years, much marine material has been collected during the BioFar and BioIce programmes, but the amphipod collections from these programmes have not yet been worked out. In addition, Norwegian marine biologists, primarily Torleiv Brattegard, the late Torleif Holthe and Jon Arne Sneli, have during the 1970s and 1980s brought together large collections of marine animals from the continental slope and abyssal plain of the Norwegian Sea; this material rests in the collections of the Zoological Museum, Bergen.

In the year 2009, Vader and Tandberg, with financial support from the Norwegian Academy of Sciences, organized an International Amphipod Workshop in Skibotn, $\mathrm{N}$. Norway, where part of these collections, that is material from deeper than $1,000 \mathrm{~m}$, was sorted and in many cases preliminarily identified. In 2011, the present authors, again 
with support from the Norwegian Academy of Sciences, got the opportunity to describe the Maeridae and Leucothoidae from this material in more detail, and we present here the results of this study.

\section{Material and methods}

Samples were taken mainly by RP bottom sledge. The amphipods were fixed using 3-5\% formalin, then washed, preserved in $70 \%$ alcohol and sorted under a dissecting microscope. Slides were prepared with glycerine and/or Faure's medium. Pencil drawings were done using various compound microscopes with camera lucida; the transfer or "inking" was done by hand as well as using the program Adobe Illustrator.

All examined material is deposited at the Crustacean collection of the Zoological Museum, Bergen.

\section{Systematics}

Family Maeridae Krapp-Schickel, 2008

\section{Maera loveni (Bruzelius, 1859) (Figs. 1, 2)}

Gammarus loveni Bruzelius 1859: 59

Maera loveni Bate 1862: 193; Norman 1869: 416; Sars 1895: 519, pl. 182; Stebbing 1906: 438; Shoemaker 1930: 116; Schellenberg 1942: 44; Gurjanova 1951: 757-758, fig. 526; Lincoln 1979: 286, fig. 133; Krapp-Schickel and Jarrett, 2000: 34, fig. 4.

Maera tenera G.O. Sars, 1885 (cf. also Stephensen 1940: 311 who already proposed this synonymy)

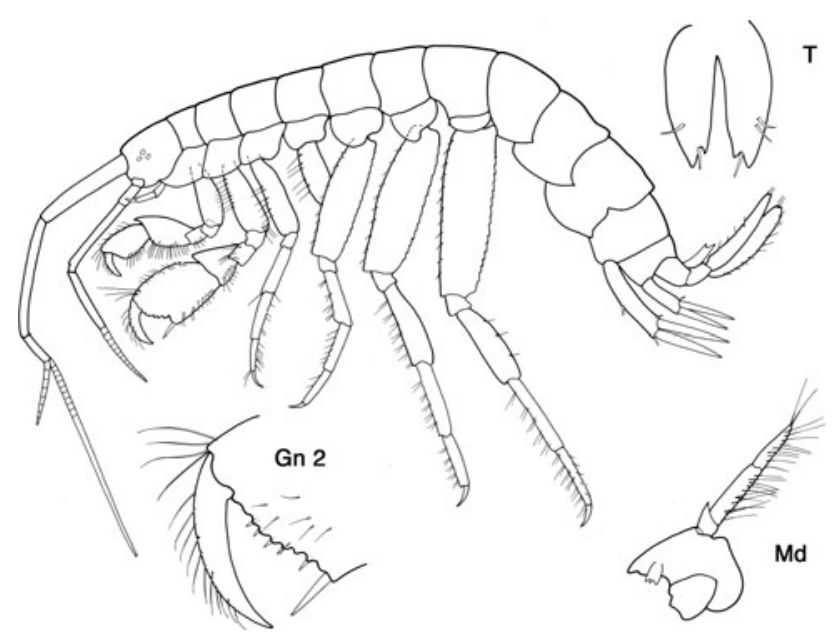

Fig. 1 Maera loveni (Bruzelius, 1859): habitus; Gn 2 gnathopod 2; Md mandible, $T$ telson
Maera prionochira von der Brüggen 1907: 230, Figs. 5, 6, 7 (figure captions are most probably switched: what is labelled as Gn 1 is the normal Gn 2, and what is labelled as Gn 2 must be an anomaly. But Ep 3 and T shape are matching).

Type locality Bohuslän, Koster Islands, Gullmarfjord, "locis profundioribus".

Material examined 1 male $34 \mathrm{~mm}, 83.06 .03 .2,1.220 \mathrm{~m}$ depth, $60^{\circ} 12,1^{\prime} \mathrm{N}, 06^{\circ} 37,5^{\prime} \mathrm{W} 1983$ 3/VI.

Diagnosis Largest member of the Maera sensu strictogroup; diagnostic differences are the very little visible ommatidia of the small eyes, long flagellum in A 1, the anteriorly acutely lengthened $\mathrm{Cx} 1$, the long spine on the palmar corner of $\mathrm{Gn} 2$, the posterodistal corner of Ep 1-3 with upturned acute tooth, and the asymmetrically incised lobes in the telson with one spine inserted on the inside.

Redescription (using the original one by Bruzelius, completed by the allometric differences of the present specimen):

Body Uncommonly elongate and narrow, back completely smooth. [Length of type material $20 \mathrm{~mm}$, up to $37 \mathrm{~mm}$ after Shoemaker 1930: 334; in the present specimen $34 \mathrm{~mm}$ ].

Head Lateral cephalic lobe regularly rounded, anterodistal corner acute. Eyes small [with scattered ommatidia, which are pale and scarcely visible in alcohol].

A1 reaching segment 4 of the abdomen, about twice as long as A 2, regularly beset with short setae; peduncle art 1 long and narrow, but thicker and shorter than art 2; [art 3 about $1 / 3$ length of art 2]; flagellum with about 30 arts, acc. flag. with 7-8 arts.

A 2 ped art 3 much shorter and somewhat thicker than art 4, art 4 subequal art 5 [here art $4>$ art 5], art 4 longer than end of A 1 peduncle art 1; art 5 does not reach the end of A1 ped art 2 [does reach it here]; flagellum somewhat shorter than peduncle art 5 [here subequal], consists of 10-12 arts [here 13].

Mouthparts Mandibles strong, with high molar; palp with 3 arts, the second the longest, art 1 the shortest and with tooth-shaped prolongation. Mx1 IP narrow, distally with 3-4 plumose setae; [OP with bifurcate robust spines]; Mx 2 lobes elongate, densely beset with long marginal setae [partly plumose; on IP also facial setae]. Mxp IP reaches about half of palp art 2, distally with dense setae; OP (=ischium) reaches about $1 / 3$ of palp art 2 (=carpus), along inner margin strong spines which are toothed on one side, distally with setae; art 2 of the palp is the longest and is also densely beset with spines and setae. UL rounded, LL divided into large rounded lobes with short processes anterodistally.

Peraeon Coxal plates short, $\mathrm{Cx}$ 1, 2 smaller than Cx 3, 4 [here clearly the opposite]. Cx 1 anterodistal corner acutely produced, all other coxae rounded. 

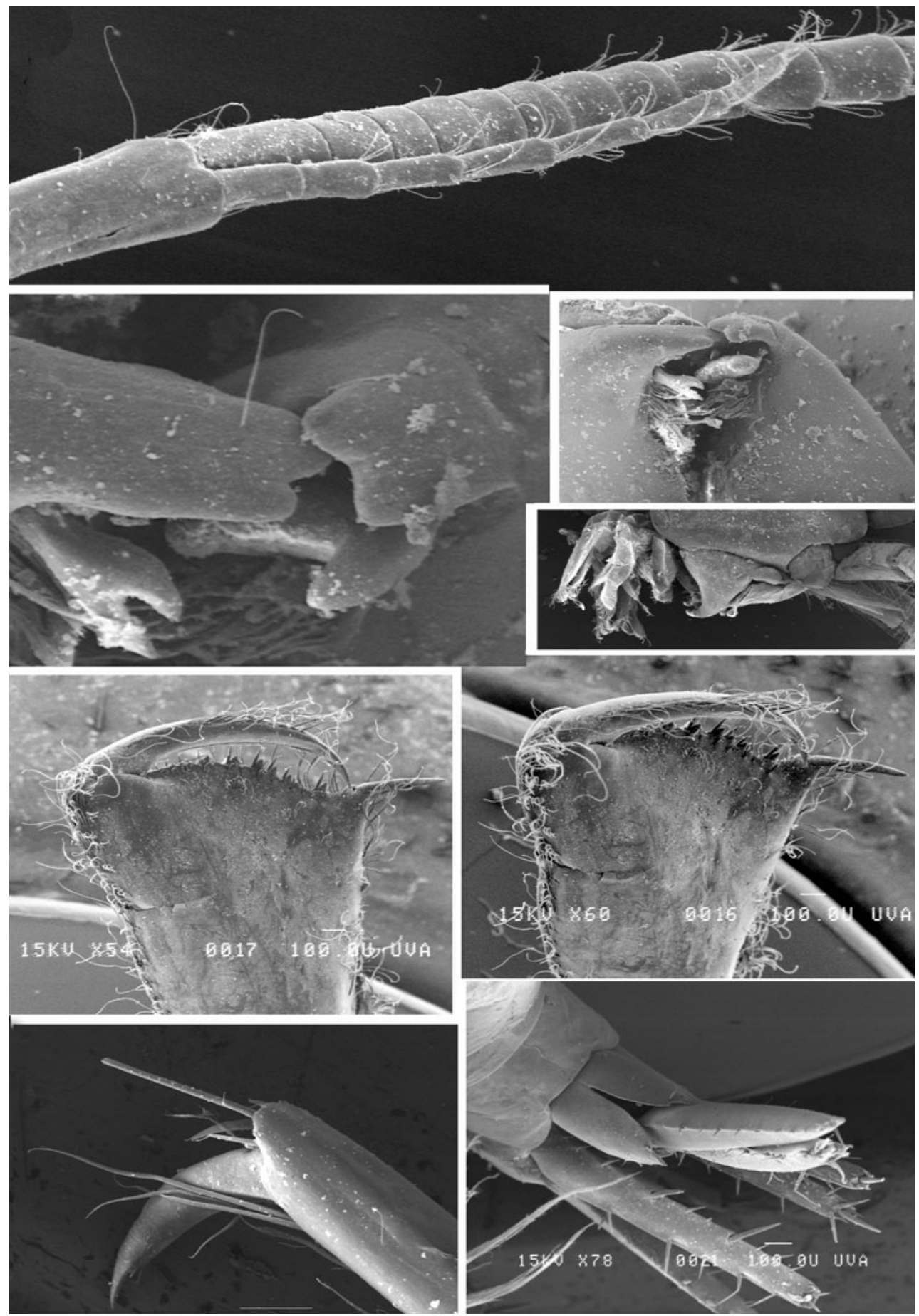

Fig. 2 Maera loveni (Bruzelius, 1859): SEM pictures. Upper half first antenna with accessory flagellum. Directly underneath: mouthpart-details (on left and right side the two mandibles working together, on right side an overview of the mouthpart bundle, laterally

Gn 1 much smaller than Gn 2 Carpus subequal to propodus [here longer], anterodistal corner acute, posterior margin rounded; anterior margin almost without setae, a number of oblique rows of densely long setae along the posterior margin; [propodus distally widening, posterior margin regularly seen). Lower half: second gnathopod in two different positions. Lowest left: dactylus and propodus of peraeopod 7. Lowest right: telson and uropods seen from dorsally

rounded]; also facial setae on both sides. Dactylus strong, outer margin with long and fine setae, but no spines.

Gn 2 carpus [triangular] Much smaller than propodus, on posterior margin very dense setae; propodus almost 
rectangular, proximal part somewhat narrower than distal one. Palm slightly convex, with 7-8 small acute humps beset with shorter spines and longer setae; palmar corner with a strong, straight and acute spine, posterior margin with dense short setae.

$P 3$ somewhat longer than P 4 Subsimilar: basis long and narrow, ischium short, merus, carpus and propodus gradually shorter; dactylus short [robust].

P 5-7 uncommonly narrow bases (in the type material of $20 \mathrm{~mm}$ ) Distally narrowing [in our specimen of $34 \mathrm{~mm}$ bases not so narrow], [anterior margin beset with short setae, posterior margin finely serrated; in P 5 basis proximally rounded, in $\mathrm{P}$ 6, 7 basis with posteroproximal lobe]; dactyli strong, convex and acute.

Pleon Ep 1, 2, 3 all with small upturned sharp tooth on posterodistal corner.

$\mathrm{U} 1$ peduncle longer than subequal rami and reaching somewhat further than $\mathrm{U} 2$, with one strong spine along half of anterior margin and two spines distally; rami beset with short spines along the margins and distally; $\mathrm{U} 2$ peduncle shorter than subequal rami, U 3 reaching much further than $\mathrm{U} 1,2$, rami flattened, subequal in length, margins with shorter, distal end with longer setae and fine spines.

Telson deeply cleft, but not quite to the basis, lobes diverging, distally narrowing and with short $\mathrm{V}$-shaped incision [inner arm of this " $\mathrm{V}$ " much shorter], beset with one strong spine [which is subequal or somewhat longer than outer arm of incision].

No sexual differences observed; the female has only slightly shorter appendages.

Colour Pale.

Distribution North Atlantic, American and European coasts; Arctic Ocean; Greenland; Iceland; European coasts from northern Norway to British Isles. Depth range as yet only known from 6 to $400 \mathrm{~m}$. Now down to $1,220 \mathrm{~m}$.

For a key to all 12 Maera species worldwide (M. anoculata, M. danae, M. edwardsi, $M$. fusca, $M$. grossimana, M. hirondellei, M. loveni, M. pachytelson, M. schieckei, M. similis, M. sodalis, M. tinkerensis) see Krapp-Schickel and Jarrett 2000: 29 .

Leucothoidae Dana, 1852

Leucothoe aff. spinicarpa (Abildgaard, 1789) (Figs. 3, 4)

Krapp-Schickel 1989; Krapp-Schickel and Menioui 2005, 64-66; Crowe 2006: 57-68.

Material examined 1 ? fem. $6 \mathrm{~mm}, 4$ immatures 4-5 mm, $1,542-1,560 \mathrm{~m}$ depth, $62^{\circ} 28.1^{\prime} \mathrm{N}, 14^{\circ} 13.4^{\prime} \mathrm{W}$, Stn 83.06.06.1, 1983 6/VI.

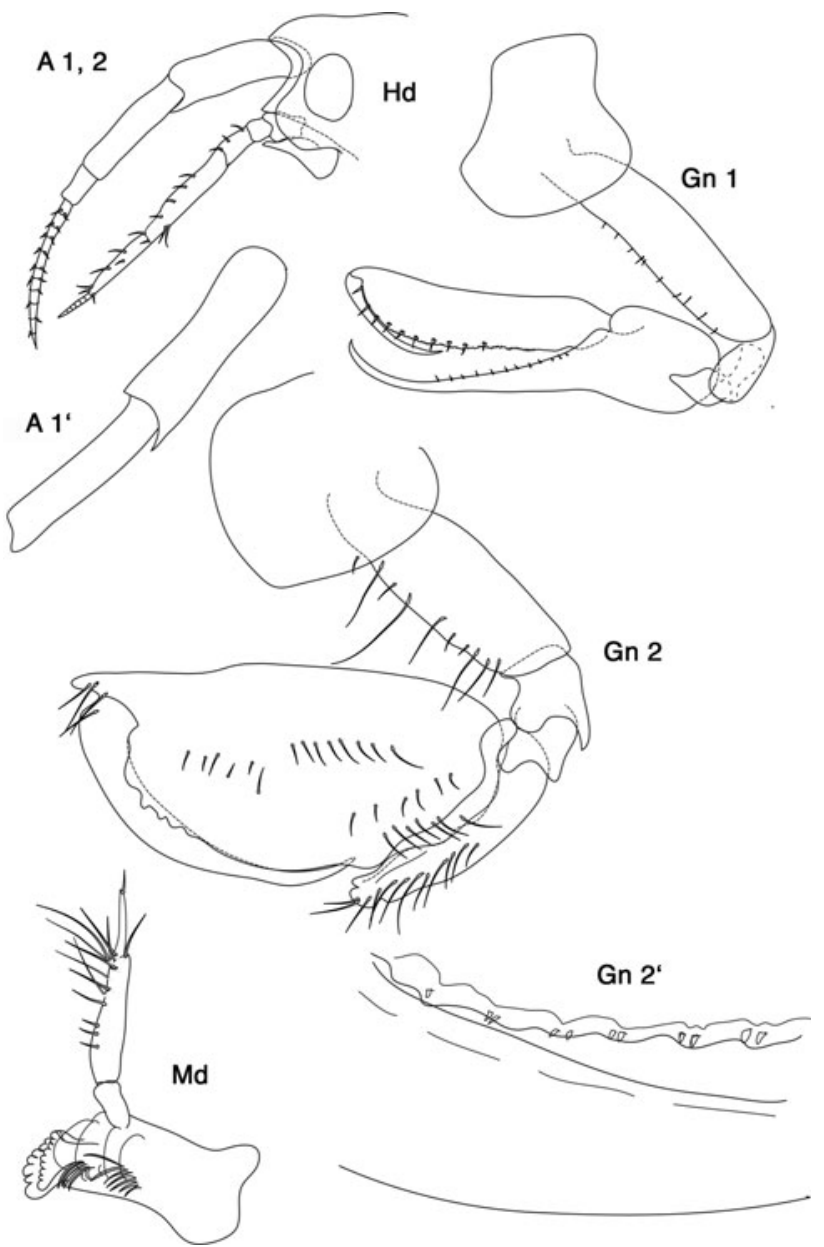

Fig. 3 Leucothoe aff. spinicarpa (Abildgaard, 1789): A 1, 2 antenna 1, 2; A $1^{\prime}$ first antenna peduncle article 1,2 enlarged. $H d$ head. $G n 1$, 2, Gn $2^{\prime}$ parts of dactylus and propodus enlarged. $M d$ mandible

Diagnosis Eyes oval. Mandibular palp long and narrow, art 3 half length of art 2. Cx 1 inferior margin smooth, about as long as wide. Gn 1 carpus distal part about $6 \times$ longer than wide, dactylus reaching about $0,3 \times$ of propodus length. P 3, 4 with very narrow basis, P 5-7 basis ovally broadened, with regularly rounded hind margin, ratio length to width $2.5: 4$ or $3.5: 5$. Ep 2 posterodistally with upturned tip, Ep 3 distoposterior corner with right angle, blunt, anterior corner lacking setae.

Description Length 4-6 mm.

Head Anterior margin rounded, anterodistal margin rectangular with rounded corner. Mid-cephalic keel with acute projection. Rostrum small.

Eyes oval Antenna 1 one-third of body length, flagellum 11- articulate, peduncle art 1 width proximally less than twice article 2, disto-inferiorly with acute tooth, length art 1 subequal art 2 , art 3 about $1 / 3$ of art 2 , acc. flagellum not seen. 

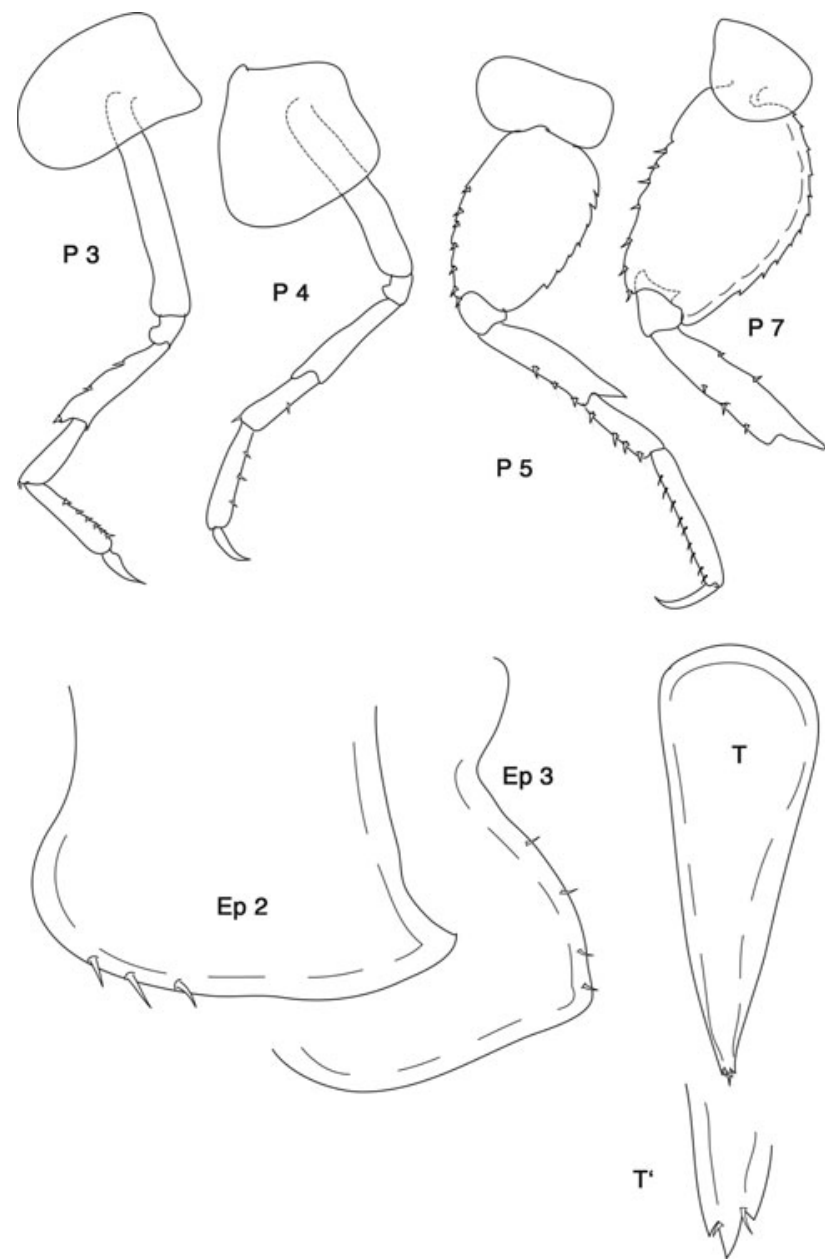

Fig. 4 Leucothoe aff. spinicarpa (Abildgaard, 1789): P 3-7 peraeopods. Ep 2, 3 = epimeral plates 2, 3. $T$ telson, $T^{\prime}$ distal end of telson enlarged

Antenna 2 one-third of body length, subequal in length to antenna 1 , peduncle art $4>$ art 5 , flagellum 6 arts.

Mouthparts Mandibles lacking molars, palp 3-articulate, ratio of articles $1-3$ is about $1: 2,8: 1.4$, art 2 with $8-9$ long lateral and 1 distal setae, art 3 with 1 distal seta, incisors strongly dentate.

Peraeon Cx 1-4 relative widths 1.0: 1.2: 0.8: 1 .

Cx 1 smooth, length and width subequal; anterior margin smooth, excavate, anterodistal margin produced, anterodistal corner about $120^{\circ}$, distal margin regularly rounded, smooth, posterior margin excavate, facial setae absent.

Gn 1 basis not inflated, with small tiny setae on anterior margin; ischium smooth; carpus distal part linear, length about $6 \times$ width; propodus straight, palm dentate with 9 short spines; dactylus smooth, reaching about $0.3 \times$ propodus length.

Cx 2 about as long as wide, subquadrangular, much wider than Cx 3, distally smooth; anterior margin straight, anterodistal corner rectangular, inferior margin rounded, posterior margin straight, facial setae absent.
Gn 2 basis slightly inflated, on anterior margin 10 setae of different length; carpus nearly reaching half propodus length, curved, distally truncate, densely setose; propodus distally with tooth-shaped prolongation, palm convex with many low humps, with ?2 mediofacial setal rows, with a few submarginal setae, proximally near dactylus end widening with clear corner of about $120^{\circ}$; dactylus curved, both margins smooth, bare, reaching somewhat more than half of propodus length.

Cx 3 length > width, smooth, bare, anterior and posterior margin straight, distally rounded, facial setae absent.

Cx 4 wider than long, smooth, bare, anterior margin somewhat convex, distal margin scarcely rounded, posterior margin shorter than anterior one, excavate, facial setae absent.

P 3, 4 basis very narrow, about the width of merus and up to $6-7 \times$ the width of basis; dactylus reaching nearly half length of propodus, posterior margins with short and thin spines.

Cx 5-7 facial setae absent.

P 5-7 similar, bases length: width ratio about 1.4-1.6, anterior margins with slight serrations and small weak spines, posterior margins strongly serrate.

Pleon Ep 1 posteroventral corner rounded. Ep 2 with spines on distal margin, posteroventral corner acutely produced. Ep 3 posteroventral corner blunt and rectangular, distally bare, but some short spines on posterior margin.

U 1-3 relative lengths 1.0: 0.8: 1.1 .

Telson Ratio length: width about 3, tip tridentate because of two indentations near distal end, with a short seta inserted in each one.

Remarks These specimens undoubtedly belong to the "spinicarpa"-group.

We started out with the supposition that material of more than 1,500 m depth cannot be $L$. spinicarpa which primarily is a shallow water species. Sars (1891) writes "30-150 fathoms", while Lincoln (1979) records the species as "occasionally intertidally, down to $600 \mathrm{~m}$ ". Our material contains no specimens with signs of sexual maturity, and we know extremely little about the life span, variability or allometry in $L$. spinicarpa. The species has been redescribed by Krapp and Menioui (Krapp-Schickel and Menioui 2005) and by Crowe (2006) on the basis of topotypical material; Crowe also designed a male neotype of $13 \mathrm{~mm}$, deposited in the Zoological Museum of Oslo.

L. spinicarpa (Abildgaard, 1789) is one of the earliest amphipods to be formally described, and the description is correspondingly vague. Shortly after also the species L. articulosa Montagu, L. denticulata A. Costa and L. antarctica Pfeffer were described, all morphologically quite 
similar to $L$. spinicarpa and all for a long time synonymized with that species. L. denticulata was re-established and fully described by Krapp-Schickel and Menioui (2005), and the redescription of $L$. antarctica is in preparation, but a modern redescription of $L$. articulosa, also revived by KrappSchickel and Menioui (loc. cit.), is still lacking.

Sars (1890-1895) revised the species and described L. spinicarpa from Norway, synonymizing $L$. articulosa (type locality S-Devonshire, type material also lost) with it. But in his illustration on pl. 101 (sub male L. articulosa of $16 \mathrm{~mm}$ ), Ep 3 has a small but well-defined posterodistal tooth-shaped tip, which is still more acutely illustrated in the drawing of L. articulosa by Bate and Westwood 1863 Fig. 3, while Lincoln 1979 describes Ep 3 in his material (sub L. spinicarpa) as "quadrate OR with minute blunt tooth"; in the illustration of the neotype, Ep 3 is posterodistally rectangular.

Crowe (2006) specified several characters useful for comparison within the "spinicarpa-group": the number of flagellum articles on the antenna 1 and 2; the anterior setation of the basis and the mediofacial setae on the propodus of gnathopod 2; the propodus and dactylus length of pereopods 3-7; the shape and setation of epimera 3 and the telson.

Our material $(4-6 \mathrm{~mm})$ is not fully mature, and therefore a number of these characters cannot be applied here, for example the antennar articles. The deepwater specimens deviate in a few points from CROWE's redescription of L. spinicarpa: Gn 2 carpus is distally rounded (as in females and juveniles of $L$. spinicarpa, but differing from adult males). Ep 1 lacks anterodistal setae in our material, and the mediofacial row (or 2 shorter rows?) of setae on the propodus of $\mathrm{Gn} 2$ has a quite different shape than in Crowe's material.

As our material does not contain obvious males and none of the specimens seems to be fully adult, we refrain from describing a new species and design our material as L. aff. spinicarpa.

Leucothoe ushakovi Gurjanova, 1951 (Figs. 5, 6, 7)

Gurjanova 1951: 487-488, fig. 320 A, B

Material examined 10 specimens of 8-27 mm length, $3,892 \mathrm{~m}$ depth, $65^{\circ} 39,9^{\prime} \mathrm{N}, 04^{\circ} 35,8^{\prime} \mathrm{W}$, Stn 83.06.09.1, 1983 9/VI

\section{Type locality Greenland Sea.}

Diagnosis Eyes apparently absent in fixed material. Mandibular palp long and narrow, art 3 up to $2.5 \times$ shorter than art 2. Cx 1 inferior margin weakly serrate, ratio length: width in large animals up to 2 . Gn 1 carpus distal part about $10 \times$ longer than wide, dactylus reaching $0.25 \times$ of propodus length. P 3-7 with very narrow and similar basis, ratio length to width up to 4 in $P$ 5-7, up to 7-8 in P 3, 4. Ep 2, 3 posterodistally with upturned tooth. $\mathrm{U} 1-3$ peduncle always longer than rami.

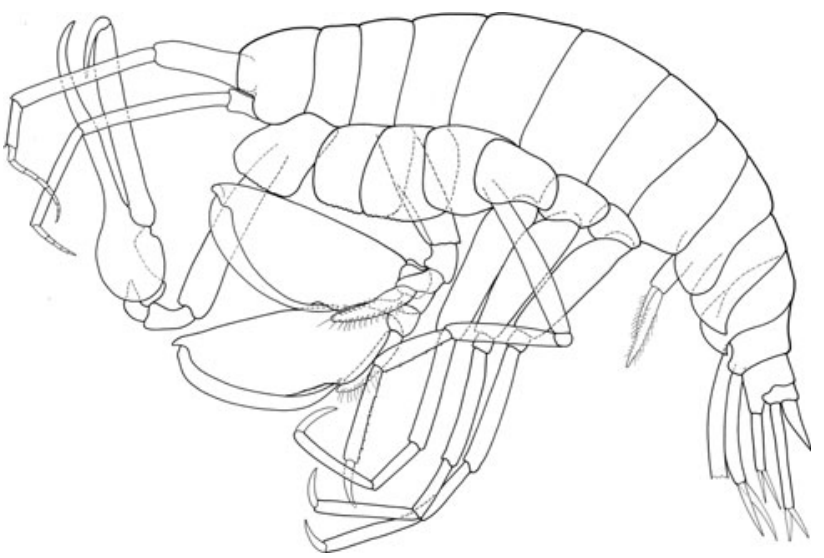

Fig. 5 Leucothoe ushakovi Gurjanova 1951: habitus

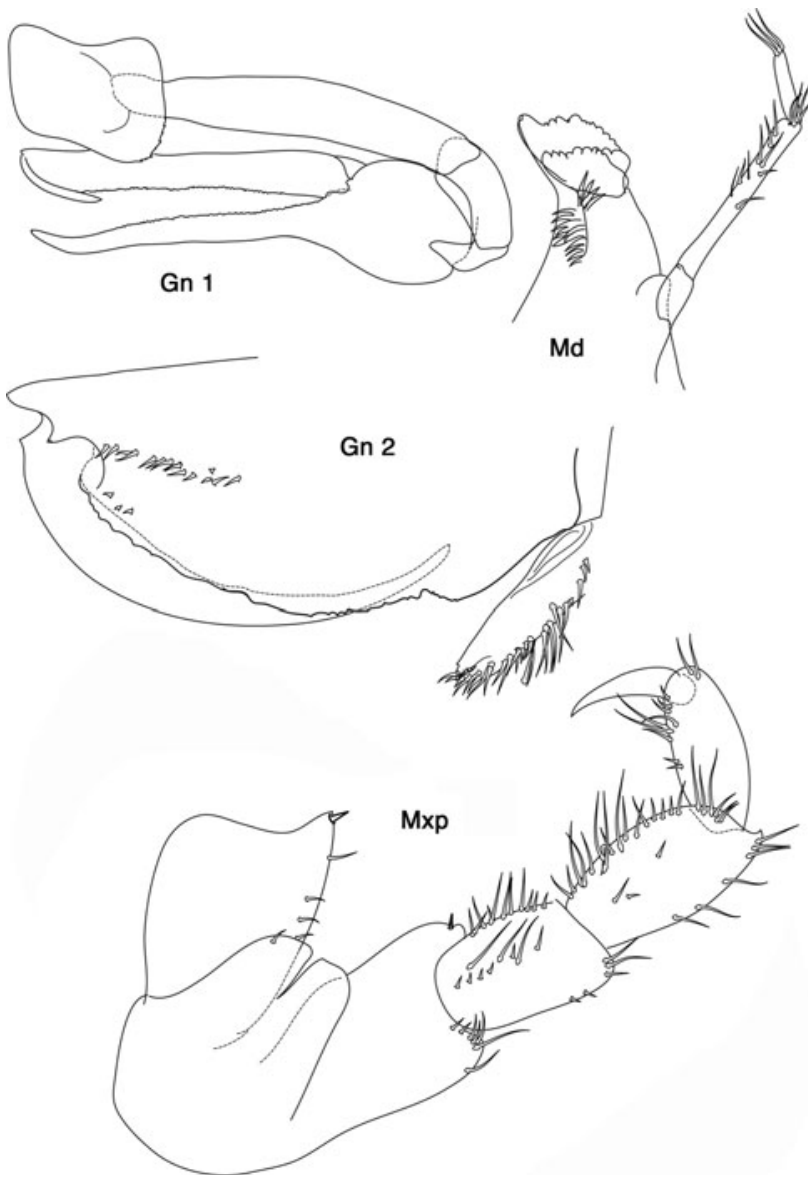

Fig. 6 Leucothoe ushakovi Gurjanova 1951: Gn 1, 2 gnathopod 1, 2; $M d$ mandible, Mxp maxilliped

\section{Redescription Length up to $34 \mathrm{~mm}$.}

Head Anterior margin rounded, anterodistal margin rectangular with rounded corner. Ventral cephalic keel anteroventral margin without projection. Rostrum acute, small.

Eyes apparently absent in fixed material. 

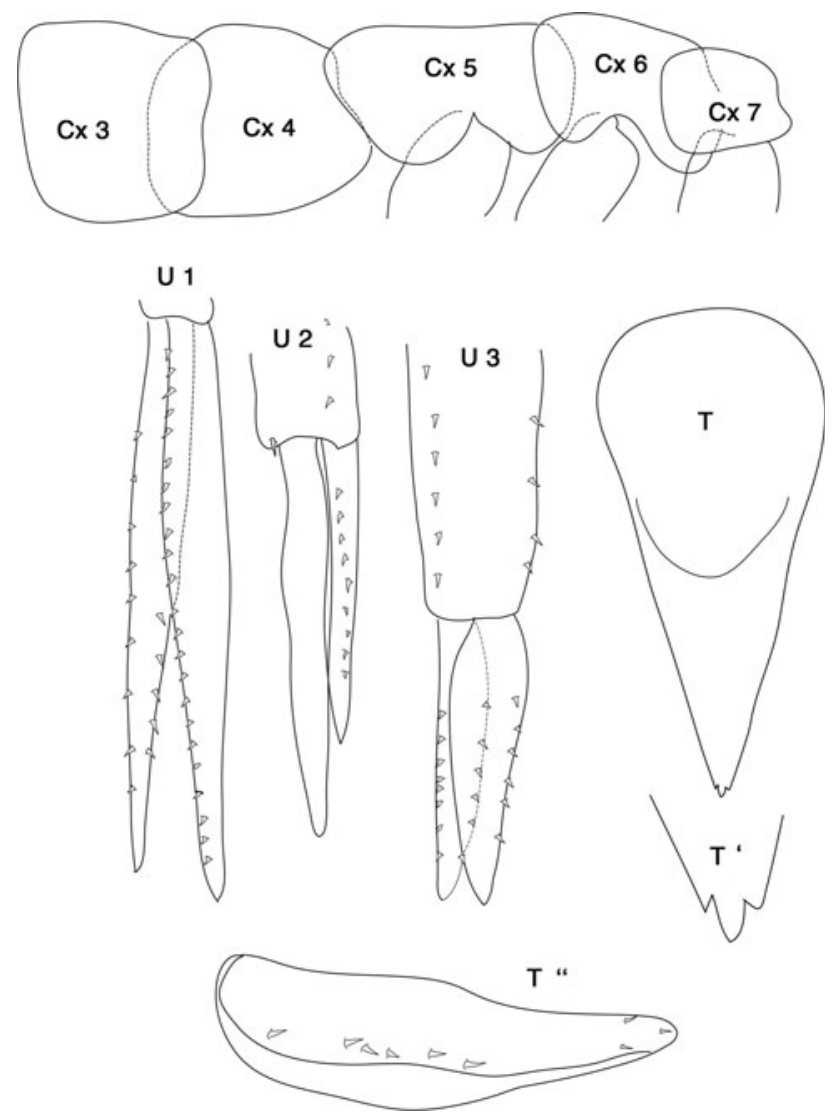

Fig. 7 Leucothoe ushakovi Gurjanova 1951: Cx 3-7 = coxal plates; $U$ 1-3 = uropods; $T$ telson, $T$ and $T^{\prime \prime}$ enlargement of telson distally and laterally

Antenna 1 one-third of body length, flag 6-15 articulate, ped art 1 width proximally about twice art 2 , length art $1<$ art 2, art 3 half length art 2, acc. flag with 1 small art.

Antenna 2 one-third of body length, subequal in length with A 1, ped art 4> art 5, flag 6-10 arts.

Mouthparts Mandibles lacking molars, palp 3-articulate, ratio of articles $1-3$ is about 2: 6.5: 2.7 or 1.8: 6.2 : 3 , art 2 with 8-9 long lateral and 3 distal setae, art 3 with 2-3 distal setae, incisors strongly dentate; left mandible lacinia mobilis large, strongly toothed, with 16 raker spines; right mandible lacinia mobilis small, with 16 raker spines.

Lower lip inner lobes fused, bare; outer lobes with small gap.

Mx 1 palp with 2 arts, with 2 distal setae; outer plate with distal spines and setae, inner plate naked. Mx 2 inner plate with many thin marginal and a few facial setae; outer plate with few distal setae. Mxp inner plates fused, distal margin with a $\mathrm{v}$-shaped indentation; outer plate triangular, reaching $0.3 \times$ palp art 1 , with one subdistal spine; palp with 4 arts, art 2 and art 3 with marginal and facial setae, dactylus < <art 3.
Peraeon Cx 1-4 relative widths 1.0: 1.3: 1.3: 1.5 .

Cx 1 smooth, in smaller specimens ratio length to width about 11: 8 , in larger ones up to 2 : 1 ; anterior margin smooth, anterodistal margin produced, rounded, distal margin straight, with some dentations, posterior margin excavate, facial setae absent.

Gn 1 basis scarcely inflated, naked; ischium with posterior setae; carpus distal part linear, length about $10 \times$ width, proximal margin finely serrated; propodus straight, palm dentate with 10 short setae; dactylus smooth, reaching $0.25 \times$ propodus length.

Cx 2 about as long as wide, subquadrangular, wider than Cx 3, distally weakly dentate; anterior margin straight, anterodistally rectangular, inferior margin straight, posterior margin straight, facial setae absent.

Gn 2 basis slightly inflated, naked; carpus $0.3 \times$ propodus length, curved, distally truncate, densely setose; propodus distally with tooth-shaped prolongation, posterior margin smooth, with 1 mediofacial setal row, with a few submarginal setae, palm convex and dentate, proximally near dactylus end widening with angle of about $120^{\circ}$; dactylus curved, outer margin smooth, bare, inner margin with rounded humps, reaching $0.75 \times$ propodus length.

Cx 3 length subequal width, anterodistal corner overriding distal face of $\mathrm{Cx} 2$, smooth, bare, anterior margin straight, anterodistal corner rounded, facial setae absent.

Cx 4 wider than long, smooth, bare, anterior margin somewhat convex, distal margin evenly rounded, posterior margin excavate, facial setae absent.

P 3, 4 basis very narrow, about the width of merus and up to $7-8 \times$ the width of basis; dactylus reaching $1 / 3$ of propodus, posterior margins with short and thin spines.

Cx 5-7 facial setae absent.

P 5-7 very similar, bases length: width ratio about 4 , anterior margins with very slight serrations and small weak spines, posterior margins smooth.

Pleon Ep 1 with 1 spine on inferior margin, Ep 2, 3 bare. Ep 1 posteroventral corner rounded, Ep 2, 3 posteroventral corner acutely produced.

U 1-3 relative lengths 1.0: $0.8: 1.1$. U 1 peduncle nearly twice the outer ramus which is about $0.9 \times$ of inner ramus length. $\mathrm{U} 2$ peduncle $>$ inner ramus length, outer ramus length $0.8 \times$ inner ramus length. $U 3$ peduncle about twice inner ramus length, outer and inner ramus length subequal. U 1-3 margins of peduncle, inner and outer rami all with short spines.

Telson Twice as long as wide, apex with very small $\mathrm{V}$-shaped excavation in the acute tip, with submarginal short spines.

No sexual differences observed.

Colour In alcohol somewhat yellowish, body semi-transparent. 
Distribution Greenland Sea at the depth of 3,000 m (2 specimens, types). Norwegian Sea at $65^{\circ} \mathrm{N}$ and $04^{\circ} \mathrm{W}$, 3,892 $\mathrm{m}$ depth (presently studied material)

Remarks Gurjanova (1951) reports about the type material that "Gn1 propodus is longer than basal article", which is not the case in our material, obviously due to the propodus growing allometrically. About the telson, she described that the lateral margins are "completely smooth", which was the case in some of the presently studied specimens, while others had some submarginal small spines.

\section{Remarks on the genus Leucothoe}

The amphipod genus Leucothoe is extremely easy to recognize as such, but its many species are differentiated from each other by only subtle characters, and this has traditionally led to a whole-sale lumping of many species under just a few names, esp. sub Leucothoe spinicarpa (Abildgaard, 1789). In the last years, it has become clear that the genus, with many of its species living commensally inside sponges, ascidians and even bivalve mollusks, is a very speciose one, and especially in the Pacific Ocean, there are still large numbers of as yet undescribed species (cf White and Reimer 2012a, b, c). The present identification key, which is based exclusively on the literature, is therefore restricted to the Leucothoe species of the somewhat better known Atlantic Ocean, although also in this area, there is no doubt still a considerable number of as yet undescribed species to be discovered (cf. Thomas and Klebba 2007).

As the genus Leucothoe shows both sexual differences and in many species a considerable allometry, the present key is only suitable for adult male specimens.

Recent authors, for example Thomas and Klebba 2007, have discovered a series of new and most interesting character traits, of use in the identification of Leucothoe species, such as the exact form of the mid-ventral keel and the size and placement of the various rows of setae on the $\mathrm{Gn} 2$ propodus. We have unfortunately been unable in most cases to use these characters, as they were not shown in earlier illustrations of other species.

The taxa in the spinicarpa group of species are only now being properly diagnosed and their differences catalogued, and as yet there are, for example, no modern descriptions of L. articulosa (Montagu, 1804) and of L. miersi Stebbing, 1888 (by most authors still synonymized with L. spinicarpa). In addition, we have included both L. occidentalis Reid, 1951 and L. serraticarpa Della Valle, 1893 twice in the key, as the two modern descriptions of these taxa differ in some respect from each other.

We hope that the present key may be a contribution to the further unravelling of the relationships among Atlantic Leucothoe species.
Identification key to Atlantic Leucothoe species (adult males only)

NB We have omitted those taxa considered by White (2011) in her monograph as unidentifiable or 'probably not valid'. Leucothoe campi Mateus \& Mateus, 1986 and L. spinulosa Chevreux, 1919-20, though probably valid species, are not well enough described to be included in the key. All Atlantic records of L. furina (Savigny, 1816) are suspect (cf White 2011), while White's Atlantic report of L. acanthopus Schellenberg, 1928 rests on a geographic error: the Dahlak Archipelago is in the Red Sea.

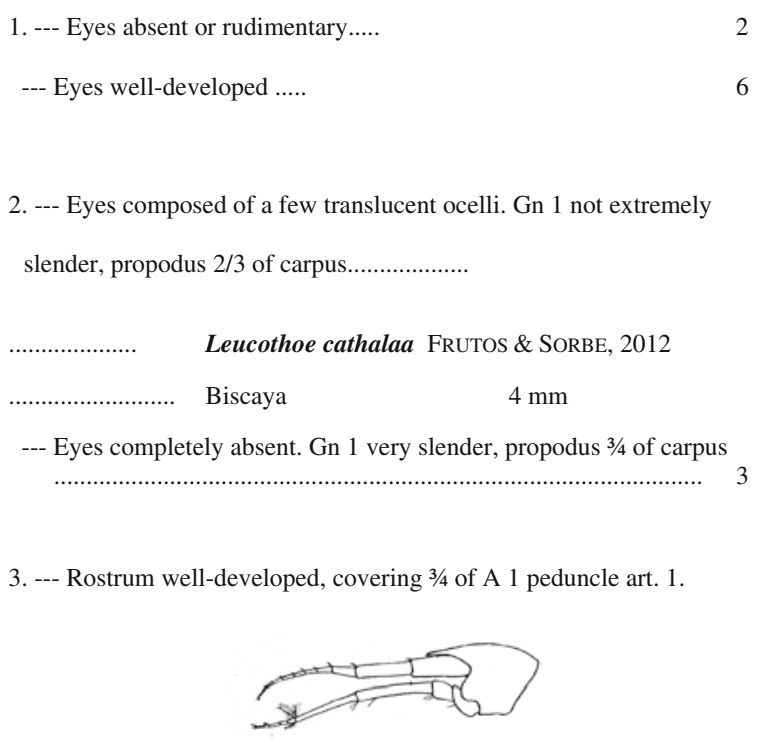

Telson short, as broad as long....... Leucothoe rostrata CHEVREUX, 1908

$$
\text { Azores, deep sea } \quad 3.5 \mathrm{~mm}
$$

(NB. Only 3 females known)

--- Rostrum short, covering less than half of A 1 peduncle art. 1. Telson

slender, at least $2 \mathrm{x}$ as long as broad......

4. --- Very large animals, up to $34 \mathrm{~mm}$. (Cx 1 almost $2 \mathrm{x}$ as long as broad. Ep 3 with well-developed posterodistal tooth)........

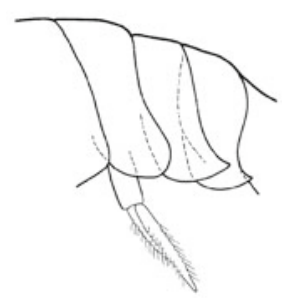

Leucothoe uschakovi GURJANOVA, 1951

Greenland Sea (deep) $34 \mathrm{~mm}$

--- Moderately large animals, 5 - $12 \mathrm{~mm}$. 
5. --- Animal up to $12 \mathrm{~mm}$. Gn 1-2 basis with anterior margin smooth. P 5 basis with posterior margin smooth

Leucothoe ayrtonia BELLAN-SANTINI, 1997

$$
\text { Barbados Trench } 12 \mathrm{~mm}
$$

(NB. Only one specimen known)

--- Animal up to $5 \mathrm{~mm}$. Gn 1-2 basis with anterior margin setose. P 5 basis with posterior margin serrate.

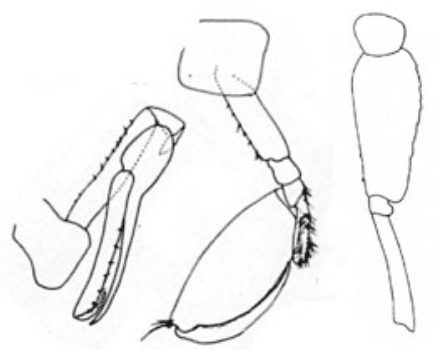

Leucothoe atosi BELLAN-SANTINI, 2007

Mid-Atlantic Ridge $(37 * \mathrm{~N}), 5 \mathrm{~mm}$

(NB. No adult males known)

6. --- Gnathopod 1 dactylus short $(<1 / 5$ propodus $) \ldots .$.

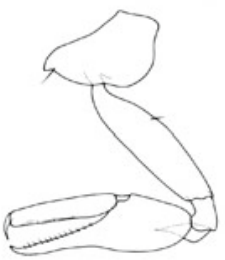

--- Gnathopod 1 dactylus long (1/4 propodus or longer).....

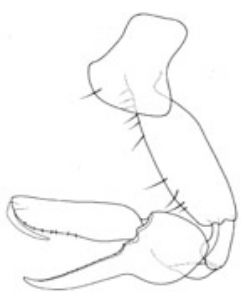

16

7. --- A 1 peduncle art. 1 greatly swollen......

8

--- A 1 peduncle art. 1 not swollen......

9

8. --- P 3-7 dactylus very slender, > $5 \mathrm{x}$ as long as broad. Gn 2 propodus about $3 \mathrm{x}$ as long as broad, palm defined by a protuberance......

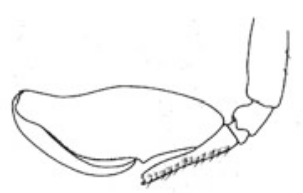

Leucothoe oboa KARAMAN, 1976

$$
\text { Mediterranean, } \quad 3-5 \mathrm{~mm}
$$

--- P 3-7 dactylus less slender, $<4 \mathrm{x}$ as long as broad. Gn 2 propodus about $2 \mathrm{x}$ as long as broad, palm not defined by a protuberance.......

Leucothoe pachycera DELLA VALLE, 1893

$$
\text { Mediterranean, } \quad 3-4 \mathrm{~mm}
$$

9. --- Ep 3 posterodistal corner rounded or rectangular....

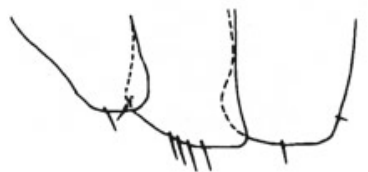

--- Ep 3 posterodistal corner clearly acute or with a small or large tooth

10. --- Gn 1 carpus densely setose. An associate of bivalve mollusks......

\section{Leucothoe flammosa THOMAS \& KLEBBA, 2007}

Caribbean, $5 \mathrm{~mm}$

--- Gn 1 carpus not densely setose......

11. --- Gn 1 carpus saw-edged by triangular teeth, with a row of strong setae.......

Leucothoe cheiriserra SEREJO, 1998

Brazil, $\quad 3 \mathrm{~mm}$

--- Gn 1 carpus not like this......

12. --- Mandible palp art. 3 long, $2 / 3$ of art. $2 \ldots \ldots$

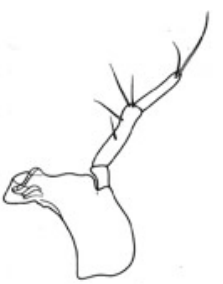

Leucothoe venetiarum GIORDANI SOIKA, 1950 
Mediterranean, $\quad 3 \mathrm{~mm}$

--- Mandible palp art. 3 short, $<1 / 3$ of art. $2 \ldots \ldots$

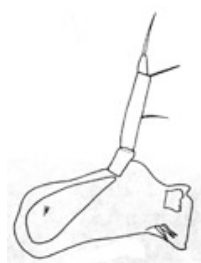

13. --- A 1 flagellum with 3-5 arts, Gn 1 propodus palm smooth, Gn 2

basis anterior margin setose, carpus distally truncate, $\mathrm{T}$ length $>2 \mathrm{x}$

width......

Leucothoe lihue BARNARD, 1970

(s. Serejo, 1998). Brazil, 3 mm

--- A 1 flagellum with 6-10 arts, Gn 1 propodus palm dentate, Gn 2 basis bare, carpus distally tapering, $\mathrm{T}$ length $<2 \mathrm{x}$ width...........

Leucothoe minima SCHELLENBERG, 1925

W. Africa, $\quad 2-3 \mathrm{~mm}$

14. --- Cx 4 anterior margin with anterodistal tooth (or at least clearly angular).

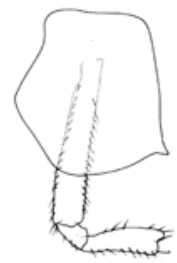

Gn 1 carpus with very fine denticulations. Ep 3 posterodistally with deep sinus and strong tooth.......

\section{Leucothoe lilljeborgii BOECK, 1861}

$$
\text { Norway, } \quad 4-5 \mathrm{~mm}
$$

--- Cx 4 anterior margin rounded. Gn 1 carpus with clear denticulations. Ep 3 posterodistally with round sinus and moderate tooth.

15. --- Telson slender, $>2 \mathrm{x}$ as long as broad, with acute tip.

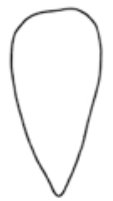

Gn 2 carpus not tapering apically, with bifid tip......

Leucothoe incisa ROBERTSON, 1892

$$
\text { Scotland } \quad 5-7 \mathrm{~mm}
$$

--- Telson wider, $<2 \mathrm{x}$ as long as broad, with rounded tip.

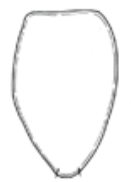

Gn 2 carpus apically tapering, with acute tip......

Leucothoe occulta KRAPP-SCHICKEL, 1975

$$
\text { Mediterranean } \quad 5-8 \mathrm{~mm}
$$

\section{6. (coming from 6: Gn 2 dactylus longer than 1/4 propodus)}

--- Ep 3 posterodistal corner rounded or rectangular......

(NB. see also 33a, or illustration for 9)

--- Ep 3 posterodistal corner acute, or with small or large tooth...

17. --- Gn 2 propodus palm smooth, or with minor serrations or crenulations......

-- Gn 2 propodus palm with sizeable protuberances......

(NB. In case of doubt, try both options)

18. --- Gn 2 propodus with conspicuous distal cap-like projection.......

Leucothoe laurensi THOMAS \& ORTIZ, 1995

Caribbean, $\quad 2-3 \mathrm{~mm}$

--- Gn 2 propodus without cap-like distal projection (but may be produced distally) ......

19. --- Lateral cephalic lobes angular or with a prominent corner......

-- Lateral cephalic lobes evenly rounded......

20. --- Gn 2 propodus palm with a row of small spines, no crenulations.

(P 5-7 basis not much expanded, almost twice as long as broad).....

Leucothoe kensleyi THOMAS \& KLEBBA, 2006

$$
\text { Caribbean, } \quad 3 \mathrm{~mm}
$$

-- Gn 2 propodus palm without a row of small spines, but with several crenulations...... 
21. --- Gn 2 basis with dense fringe of long setae. (Cx 2-4 and hind margin basis of P 5-7 smooth.)

Leucothoe garifunae THOMAS \& KLEBBA, 2007

$$
\text { Caribbean, } \quad 5 \mathrm{~mm}
$$

--Gn 2 with fewer and shorter setae

22. --- Cx 2 with anterodistal corner very acute.........

Leucothoe hortapugai WINFIELD, ORTIZ \& CHAZARO- OLVERA, 2009 Gulf of Mexico, $\quad 7 \mathrm{~mm}$

--- Cx 2 with anterodistal corner rounded

23. --- P 5 - 7 basis $1: b=5: 3 \ldots \ldots$

Leucothoe barana THOMAS \& KLEBBA, 2007

$$
\text { Caribbean, } \quad 10 \mathrm{~mm}
$$

--- P 5 - 7 basis $1: b=4: 3$ (otherwise extremely similar to the former)......

Leucothoe ortizi WINFIELD \& ALVAREZ, 2009

$$
\text { Gulf of Mexico, } \quad 6.9 \mathrm{~mm}
$$

24. --- Gn 1 dactylus not more than $1 / 4$ of propodus......(see sketches in option 6)

--- Gn 1 dactylus more than $1 / 3$ of propodus

25. ---Md palp art. 3 much shorter (1/3) than art. 2 (see sketch in option

12). Large species......

Leucothoe miersi STEBBING, 1888

\section{S. Africa, $\quad 12 \mathrm{~mm}$}

-- Md palp art. 3 2/3 as long as art. 2 (see sketch in option 12). Small species......

Leucothoe venetiarum GIORDANI-SOIKA, 1950

Mediterranean,

$3 \mathrm{~mm}$

26. --- Eyes rounded oval. Cx 1 anterodistal corner angular.

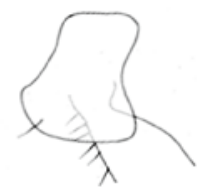

Leucothoe spinicarpa (ABILDGAARD, 1789)

NW Europe

$10-19 \mathrm{~mm}$
-- Eyes roundish or irregularly squarish. Cx 1 anterodistal corner rounded.

27. --- Gn 2 carpus distally with (a few small) spines. Eyes large, covering $1 / 2$ of head depth.......

Leucothoe occidentalis REID, 1951

$$
\text { W. Africa } \quad 5-7 \mathrm{~mm}
$$

(NB Material from Morocco by Krapp-Schickel \& Menioui, 2005; only female known)

-- Gn 2 carpus without spines. Eyes moderate, covering 1/3 of head depth.....

28

28. --- Telson very slender $(1: b=3.5: 1)$, tip acute, without setae. Gn 2 propodus with wavy, irregular crenulations....

Leucothoe articulosa (MONTAGU, 1804)

$$
\text { W. Europe, 6-13 mm }
$$

(NB. No good modern redescription of this species exists)

-- Telson slender $(1: b=2.5: 1)$, tip subacute, with two or three setules.

29. --- Gn 2 propodus palm with regular blunt serrations, stronger proximally. Gn 1 carpal lobe without elevated anterodorsal projection......

Leucothoe denticulata COSTA, 1851

$$
\text { Mediterranean, } \quad 5-15 \mathrm{~mm}
$$

--- Gn 2 propodus palm with regular acute serrations only proximally.

Gn 1 carpal lobe with elevated anterodorsal projection......

Leucothoe hendrickxi WINFIELD \& ALVAREZ, 2009

$$
\text { Gulf of Mexico, } \quad 7 \mathrm{~mm}
$$

\section{0. (coming from 17: Gn 2 propodus palm with sizeable} protuberances)

--- Md palp art. 3 clearly longer than $2 / 3$ art $2 \ldots \ldots$.

--- Md palp art. 3 clearly shorter than $2 / 3$ art $2 \ldots .$.

31. --- Gn 2 propodus palm with 6 high and narrow comb-like protuberances. Telson slender $(1: \mathrm{b}=2: 1)$, with emarginate tip....... 
Leucothoe ctenochir K. H. BARNARD, 1925

$$
\text { S. Africa, } 5 \mathrm{~mm}
$$

--- Gn 2 propodus palm with 4 proximal rounded low protuberances. Telson broad ( $1: \mathrm{b}=5: 3)$, with rounded tip........

Leucothoe basilobata SEREJO, 1998

Brazil, $\quad 3 \mathrm{~mm}$

32. --- Md palp art. 3 very short, $1 / 5$ of art. 2. (Uropods with clearly unequal rami, in $\mathrm{U} 1$ - 2 with finely serrate margins) .......

Leucothoe urospinosa SEREJO, 1998

$$
\text { Brazil, } \quad 4 \mathrm{~mm}
$$

-- Md palp art. $3 \mathrm{ca} 1 / 2$ of art. 2 .......

33. --- Gn 2 with dense tufts of long setae on arts 2 and 3.......

Leucothoe saron THOMAS \& KLEBBA, 2007

$$
\text { Caribbean, } \quad 6-7 \mathrm{~mm}
$$

-- Gn 2 without dense tufts of long setae on arts 2 and 3 (shorter setae may be present) ........

34. --- Gn 1 with very long dactylus (ca $1 / 2$ propodus). Lateral cephalic lobes angular.......Leucothoe ubouhu THOMAS \& KLEBBA, 2007

$$
\text { Caribbean, } \quad 4-5 \mathrm{~mm}
$$

--- Gn 1 with shorter dactylus (ca 1/4 propodus). Cephalic lateral lobes rounded........eucothoe ashleyi THOMAS \& KLEBBA, 2006

$$
\text { Caribbean, } \quad 3-4 \mathrm{~mm}
$$

\section{5. (coming from 16: Ep 3 posterodistal corner acute, or with small} or large tooth)

--- Gn 2 propodus palm smooth, or denticulate or crenulate....

--- Gn 2 propodus with sizeable protuberances.......

(NB. When in doubt, try both options)

36. --- Ep 3 posterodistal corner with small notch only. (P 3 propodus with 3 strong distal spines, Gn 2 propodus slender, $2.5 \mathrm{x}$ as long as broad) $\ldots \ldots \ldots$

Leucothoe leptosa SEREJO, 1998

$$
\text { Brazil, } 3 \mathrm{~mm}
$$

-- Ep 3 posterodistally with small or larger tooth........
37. --- Ep 3 with very small posterodistal tooth, without any clear

sinus 38

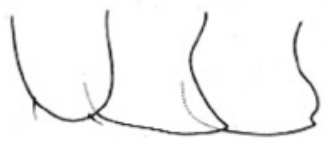

--- Ep 3 with small or moderate posterodistal tooth, demarcated above by a sinus........ 39

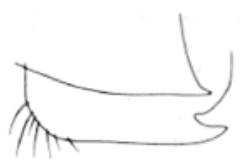

38. --Basis Gn 2 with a dense fringe of long setae. Antennae 'normal', with slender peduncles. P 5 - 7 dactyli normal. Live animals vividly red or yellowish........ Leucothoe richiardii LESSONA, 1865

$$
\text { Mediterranean, } \quad 6-8 \mathrm{~mm}
$$

--- Basis Gn 2 with only scattered setae. Antennae short, with robust peduncles. P 5 - 7 dactyli long and slender. Live animals almost transparent....... Leucothoe euryonyx WALKER, 1901

W. Africa, $\quad 2.5-3 \mathrm{~mm}$

39. --- Cx 4 with long posterodistal lobe.

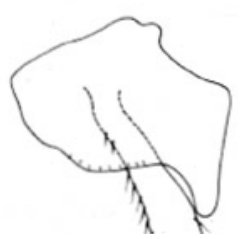

P 5 - 7 dactyli very long and slender. (Gn 1 carpus densely serrate. Cx 1 with angular corners) ........

\section{Leucothoe serraticarpa DELLA VALLE, 1893}

$$
\text { Mediterranean, } \quad 5-9 \mathrm{~mm}
$$

-- Cx 4 without long posterodistal lobe. P 5 - 7 dactyli normal or short.

40. --- P 5 - 7 basis not much expanded $(1: \mathrm{b}=3: 2)$. (Gn 2 propodus palm with proximal square excavation, corresponding to a bump on dactylus, carpus distally acute) ........

Leucothoe procera SP. BATE, 1857

$$
\text { Great Britain, } \quad 17 \mathrm{~mm}
$$


--- P 5 - 7 basis almost as broad as long.......

41. --- A 1 clearly longer than A 2. Cx 6 - 7 and basis P 6 - 7 with many

long setae...

Leucothoe prope serraticarpa s. KRAPP-SCHICKEL \& MENIOUI, 2005

$$
\text { Morocco, } 14 \mathrm{~mm}
$$

--- A 1 subequal to A 2. Cx 6 - 7 and basis P 6 - 7 with only few

setae........

Leucothoe brunonis KRAPP-SCHICKEL \& MENIOUI, 2005

$$
\text { Morocco, } \quad 6-8 \mathrm{~mm}
$$

42. ---Antennae very long (flagellum A $1>30$ arts). Gn2 propodus palm

with 3 tall narrow protuberances. Ep 3 posterodistally with deep sinus

above tooth........eucothoe dolichoceras K. H.BARNARD, 1916

$$
\text { S. Africa, } 12 \mathrm{~mm}
$$

-- Antennae normal (flagellum A 1 about 10 arts). Gn 2 propodus palm

with a few irregular low protuberances. Ep 3 posterodistally with

inconspicuous blunt tooth, without a sinus above.......

Leucothoe wuriti THOMAS \& KLEBBA, 2007

$$
\text { Caribbean, } \quad 6-7 \mathrm{~mm}
$$

Acknowledgments This study was financially supported by the Norwegian Academy of Sciences, for which we are very grateful. We are also much indebted to the intrepid collectors of Norwegian Sea material, Torleiv Brattegard (Bergen), the late Torleif Holthe and Jon Arne Sneli (both Trondheim), and to the participants of the Skibotn workshop, who have made the sorting of the many samples such a pleasant occasion. Dirk Platvoet (Amsterdam/ Leiden) provided again the SEM pictures. Finally, we are very grateful to the reviewers, K. White and O. Coleman, for their valuable comments.

\section{References}

Abildgaard PC (1789) Zoologia Danica seu animalium Daniae et Norvegiae rariorum ac minus notorum. Descriptiones et Historia. Havniae, N. Möller et filius

Bate CS (1862) Catalogue of the specimens of Amphipodous Crustacea in the collections of the British Museum. Taylor \& Francis, London

Bate CS, Westwood JO (1863) History of the British sessile-eyed Crustacea. John van Voorst, London

Bruzelius RM (1859) Bidrag til kännedomen om Skandinaviens Amphipoda Gammaridea. Kongl Svensk Vetensk-Akad Handl New Series 3:1-104

Crowe SE (2006) A redescription of Leucothoe spinicarpa (Abildgaard, 1789) based on material from the North Atlantic (Amphipoda, Leucothoidae). Zootaxa 1170:57-68
Dana JD (1852) Conspectus crustaceorum quae in orbis terrarum circumnavigatione, Carolo Wilkes e classe Reipublicae Faederate Duce, lexit et descripsit Jacobus D. Dana. Pars III (Amphipoda 1). Proc Am Acad Arts Sci 2:201-220

Della Valle A (1893) Gammarini del Golfo di Napoli. Fauna Flora Golf Neapel 20:1-948

Gurjanova E (1951) Amphipoda Gammaridea from the seas of the USSR and vicinity. Opredeliteli Faune SSSR Zool Inst Akad Nauk SSSR 41:1-1029 (In Russian)

Krapp-Schickel G (1989) Family Leucothoidae. In: Ruffo S, et al. (eds) The Amphipoda of the Mediterranean. Part 2 Gammaridea (Haustoriidae to Lysianassidae). Mém Inst Océan Monaco 13, pp 443-459

Krapp-Schickel T (2008) What has happened with the Maera- clade (Crustacea, Amphipoda) during the last decades? Boll Mus Civ Stor Natur Verona Botanica Zoologia: 3-32

Krapp-Schickel T, Jarrett NE (2000) The amphipod family Melitidae on the Pacific coast of North America. Part II. The MaeraCeradocus complex. Amphipacifica 2(4):23-61

Krapp-Schickel T, Menioui M (2005) Leucothoe species from Moroccan Atlantic coasts with redefinition of some species within the Leucothoe spinicarpa clade. Boll Mus Civ Stor Natur Verona Botanica-Zoologia 29:63-83

Lincoln RJ (1979) British marine Amphipoda: Gammaridea. British Museum, London

Mateus A, Mateus E (1986) Campagne de la 'Calypso' dans le Golfe de Guinée et aux Iles Principe, São Tomé et Annobon (1956). Amphipodes récoltés à bord de la'Calypso'. Anais Fac Ciénc Porto 66:125-223

Montagu G (1804) Description of several marine animals found on the south coast of Devonshire. Trans Linn Soc London 7:61-85

Norman AM (1869) Shetland final dredging report-Part II. On the Crustacea, Tunicata, Polyzoa, Echinodermata, Actinozoa, Hydrozoa \& Porifera. Rep thirty-eighth Meeting Brit Ass Adv Sci 38:113-141

Reid DM (1951) Report on the Amphipoda (Gammaridea and Caprellidea) of the coast of tropical West Africa. Atlantide Rep 2:189-291

Sars GO (1885) Zoology. Crustacea I. Norweg N-Atl Exped 1876-1878 6:1-280

Sars GO (1890-95) Amphipoda. An account of the Crustacea of Norway with short descriptions and figures of all the species I. Alb. Cammermeyer, Christiania \& Copenhagen

Schellenberg A (1942) Krebstiere oder Crustacea IV. Flohkrebse oder Amphipoda. Die Tierwelt Deutschlands 40:1-252

Shoemaker CR (1930) The Amphipoda of the Cheticamp expedition of 1917. Contr Can Biol Fish 5:221-359

Stebbing TRR (1888) Report on the Amphipoda collected by H.M.S. Challenger during the years 1873-1876. Rep Sci ResVoyage H.M.S. Challenger 1873-76. Zool 29:1-1737

Stebbing TRR (1906) Amphipoda I. Gammaridea. Das Tierreich 21:1-806

Stephensen K (1923) Crustacea Malacostraca. V. (Amphipoda I). Dan Ingolf-Exped 3:1-100

Stephensen K (1925) Crustacea Malacostraca. VI. (Amphipoda II). Dan Ingolf-Exped 3:101-178

Stephensen K (1931) Crustacea Malacostraca. VII. (Amphipoda III). Dan Ingolf-Exped 3:179-290

Stephensen K (1940) The Amphipoda of N Norway and Spitzbergen with adjacent waters. Tromsø Mus Skr 3(1):279-362

Stephensen K (1944) Crustacea Malacostraca. VIII. (Amphipoda IV). Dan Ingolf-Exped 3(13):1-51

Thomas JD, Klebba KN (2007) New species and host associations of commensal leucothoid amphipods from coral reefs in Florida and Belize. Zootaxa 1494:1-44 
von der Brüggen E (1907) Amphipoda. Zoologische Ergebnisse der russischen Expeditionen nach Spitzbergen. Ann Mus Zool Acad Imp Sci St Petersbourg 11:214-244

White KN (2011) A taxonomic review of the Leucothoidae (Crustacea: Amphipoda). Zootaxa 3078:1-113

White KN, Reimer JD (2012a) Commensal Leucothoidae (Crustacea, Amphipoda) of the Ryukyu Archipelago, Japan. Part I: ascidian dwellers. ZooKeys 163:13-55
White KN, Reimer JD (2012b) Commensal Leucothoidae (Crustacea, Amphipoda) of the Ryukyu Archipelago, Japan. Part II: spongedwellers. ZooKeys 166:1-58

White KN, Reimer JD (2012c) Commensal Leucothoidae (Crustacea, Amphipoda) of the Ryukyu Archipelago, Japan. Part III. coralrubble. ZooKeys 173:11-50 